\title{
Recovery of Amino Acid from the Protein in the Head and Viscera of Frigate Mackerel by Autolysis*
}

\author{
Katsuji Morioka, Shin-ya Fujii, Yoshiaki Itoh, \\ Chengchu Liu, and Atsushi Obatake
}

\begin{abstract}
Laboratory of Aquatic Product Utilization, Faculty of Agriculture, Kochi University, Nankoku, Kochi 783-8502, Japan
\end{abstract}

(Received July 27, 1998)

\begin{abstract}
The digestive conditions were investigated to recover amino acids and peptides from the protein by autolysis from the viewpoint of the effective utilization of the wastes of frigate mackerel.

Protein in the head-viscera mixture was efficiently and easily autolyzed at $15^{\circ} \mathrm{C}$ for $24 \mathrm{~h}$ at neutral $\mathrm{pH}$. Eighty-seven percent of protein in the mixture were recovered as extractive nitrogen and the autolytic extract obtained was rich in free amino acids and peptides. The hot water extract obtained from the autolyzate had umami taste. These results suggested that this autolytic extract can be used as a seasoning material.
\end{abstract}

Key words: frigate mackerel, wastes, autolysis, protein, amino acid

The development of traffic network and the advanced technology to transport food at low temperature have made it possible to transport fish as fillet to the urban area after filleting the fish in processing plant near the fishing port. Recently, such transportation network has grown rapidly in Shikoku Island, Japan.

In processing plants, the head and the viscera of fish are automatically cut off from the trunks and are disposed of as fish wastes or used for the production of fish meal and fertilizer. The fish wastes are rich in nutrients such as lipid and protein. A better utilization of the fish waste is required not only from the viewpoint of effective utilization of the fish waste, but also to prevent the environmental pollution.

In a previous study, ${ }^{1)}$ we examined the seasonal variations of lipid content and fatty acid composition of the lipid from frigate mackerel from the viewpoint of the effective utilization of fish by-products. We found that the head portion, which accounted for about $40 \%$ of fish byproduct, contained $15.1 \%$ crude protein and $11.7 \%$ crude fat. Most of the proteins in the head portion are presumed to be water-insoluble proteins such as myofibrillar and stroma proteins and are difficult to collect. These protein fractions would be easily recovered as amino acids by proteolysis. Miyake ${ }^{2-5)}$ reported the solubilization of fish scraps by enzyme treatment. In those studies, Miyake used the commercial enzymes for proteolysis. However, the high cost of commercial enzymes makes their use economically unviable for the proteolysis of the fish by-products. As suggested by Mohr, ${ }^{6}$ autolysis may provide the most promising way to produce fish protein concentrate rather than proteolysis by using commercial enzymes. Therefore, we made attempts to recover amino acid from the protein in the fish head and viscera by autolysis. This method would be advantageous to the effective utilization of fish byproducts. In this study, the autolysis conditions of wastes from frigate mackerel were examined.

\section{Materials and Methods}

\section{Materials}

Frigate mackerel Auxis rochei was purchased from the Kochi central wholesale market. Head and viscera were excised from the fish and minced with knife. The sexual organ and the content of the digestive organ were removed from viscera before mincing. Minced head and viscera were kept at $-80^{\circ} \mathrm{C}$ before use.

\section{Fractionation of Protein}

Ten grams of the minced sample (head, viscera) were homogenized with $50 \mathrm{ml}$ of distilled water. The homogenate was centrifuged at $10,000 \times g$ for $15 \mathrm{~min}$ and this step was repeated twice. The supernatants were combined and used for the determination of water-soluble nitrogen and non-protein nitrogen. Non-protein nitrogen was prepared from the supernatant by adding an equal volume of $10 \%$ trichloroacetic acid (TCA) solution. The final precipitate was homogenized with $10 \mathrm{~m} l$ of $0.1 \mathrm{~N}$ $\mathrm{NaOH}$ and stirred overnight in cold room at $5^{\circ} \mathrm{C}$. After stirring, the homogenate was centrifuged at $10,000 \times \mathrm{g}$ for $15 \mathrm{~min}$. This extraction process was repeated and the supernatants were combined, and was used for the determination of alkali-soluble protein nitrogen. Nitrogen content of each fraction and total nitrogen of the sample was determined by the Kjeldahl method. The content of water-soluble protein nitrogen was estimated by subtracting the content of non protein nitrogen in TCA extract from the content of water soluble nitrogen.

\section{Autolysis Procedure}

Minced head and viscera were mixed in the ratio $3: 1 \mathrm{w} /$ w) and the mixture was homogenized with 2 volumes of ice 
deionized water. The homogenate was transferred to a $100 \mathrm{~m} l$ Erlenmeyer flask and incubated in water bath at fixed temperature with shaking. After incubation, $10 \mathrm{~g}$ of the autolyzate was added to $10 \mathrm{~m} l$ of $10 \%$ TCA solution to stop the further autolysis and homogenized at $10,000 \mathrm{rpm}$ for $5 \mathrm{~min}$. The TCA solution obtained was kept for $30 \mathrm{~min}$ at room temperature and centrifuged at $10,000 \times g$ for 20 min. The supernatant was used for the determination of nitrogen content and amino acid composition. Nitrogen content was determined by the same method as mentioned above. To check the taste of the autolytic extract, autolysis was terminated by boiling for $10 \mathrm{~min}$ instead of adding the $10 \%$ TCA solution. After boiling, the autolyzate was centrifuged at $10,000 \times g$ for $20 \mathrm{~min}$. The supernatant obatined was used for checking the taste.

Determination of Amino Acid Composition of the Extract A portion of TCA extract was hydrolyzed in $6 \mathrm{~N} \mathrm{HCl}$ at $110^{\circ} \mathrm{C}$ for $24 \mathrm{~h}$ to determine the total content of free and bound amino acids. The content of bound amino acid in TCA extract was estimated by subtracting the content of free amino acid in TCA extract from the total content of amino acid in the hydrolyzed one. Amino acids were determined by an automatic amino acid analyzer (Hitachimodel 835).

\section{Results and Discussion}

\section{Fractionation of Protein in Head and Viscera}

The content of protein in the fish head and viscera was examined prior to the determination of autolysis conditions. As reported previously, ${ }^{1)}$ the head and viscera portions in frigate mackerel accounted for $21 \%$ and $8 \%$ of whole body weight, respectively. The head portion contained about $15 \%$ crude protein and $12 \%$ crude fat and the viscera contained about $21 \%$ crude protein and $5 \%$ crude fat. These results indicated that head portion, which accounted for about $40 \%$ of fish wastes, is rich in nutrients, such as protein and lipid. Table 1 shows nitrogen content in the head and viscera. The head contained $8.7 \%$ non-protein nitrogen and $91.3 \%$ protein nitrogen. The alkali-soluble protein nitrogen, which is assumed to be derived from muscle protein, accounted for $24 \%$ of the total nitrogen. This result indicated that a large quantity of the muscle protein was contained in the head. Most of the muscle proteins in the head are presumed to be waterinsoluble protein and are difficult to collect. However, the degradation of fish head muscle protein by proteinase would facilitate the recovery of amino acid from the protein. In general, fish viscera have a high proteinase activity. ${ }^{7-9)}$ Attempts were made to recover amino acid from the protein in the head and viscera by proteolysis.

\section{Effect of Temperature on the Autolysis}

The effect of temperature on the autolysis of the head and viscera mixture was examined. Fish digestive proteases have high activity at low temperature. ${ }^{10)}$ In this experiment, therefore, the reaction temperature was set at low temperature between 10 to $25^{\circ} \mathrm{C}$ at $5^{\circ} \mathrm{C}$ intervals. The results are shown in Fig. 1. The ordinate shows the increase in non-protein nitrogen content. The nitrogen content in the extract before autolysis was defined as $100 \%$.
Table 1. Fraction of protein in the head and viscera from frigate mackerel

\begin{tabular}{|c|c|c|c|c|c|}
\hline \multirow[b]{2}{*}{ Portion } & \multirow[b]{2}{*}{$\begin{array}{l}\text { Non-protein } \\
\text { nitrogen }\end{array}$} & \multicolumn{3}{|c|}{ Protein nitrogen } & \multirow[b]{2}{*}{$\begin{array}{c}\text { Total } \\
\text { nitrogen }\end{array}$} \\
\hline & & $\begin{array}{l}\text { Water- } \\
\text { soluble } \\
\text { fraction }\end{array}$ & $\begin{array}{l}\text { Alkaline- } \\
\text { soluble } \\
\text { fraction }\end{array}$ & $\begin{array}{l}\text { Alkaline- } \\
\text { insoluble } \\
\text { fraction }\end{array}$ & \\
\hline Head & $\begin{array}{r}226^{* 1} \\
(8.7)^{* 2}\end{array}$ & $\begin{array}{c}885 \\
(34.1)\end{array}$ & $\begin{array}{c}624 \\
(24.0)\end{array}$ & $\begin{array}{c}864 \\
(33.2)\end{array}$ & $\begin{array}{c}2599 \\
(100.0)\end{array}$ \\
\hline Viscera & $\begin{array}{r}1575 \\
(49.1)\end{array}$ & $\begin{array}{c}968 \\
(30.2)\end{array}$ & $\begin{array}{c}359 \\
(11.2)\end{array}$ & $\begin{array}{l}304 \\
(9.5)\end{array}$ & $\begin{array}{c}3206 \\
(100.0)\end{array}$ \\
\hline
\end{tabular}

$*_{1} \mathrm{mgN} / 100 \mathrm{~g}$.
* $_{2}$ Percentage.

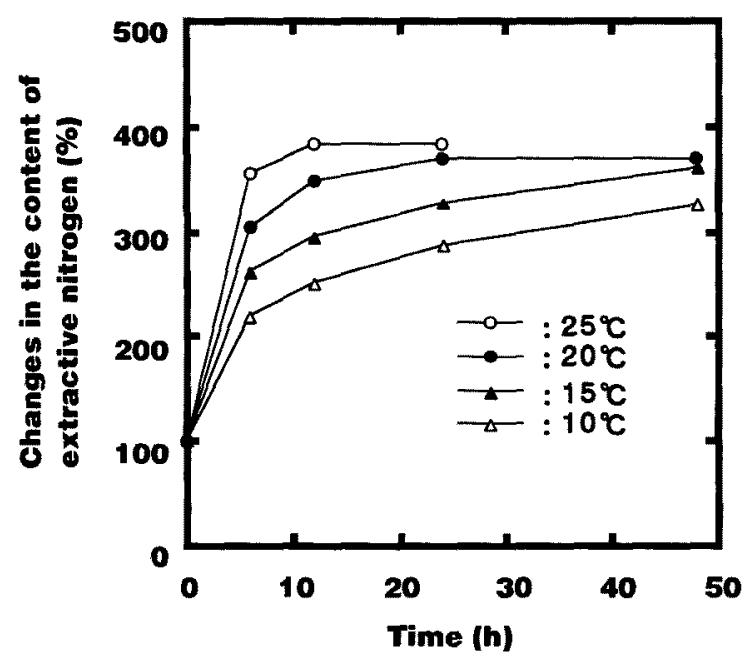

Fig. 1. Effect of temperature on the autolysis efficiency of the mixture of head and viscera from frigate mackerel.

The nitrogen content of all autolyzates increased rapidly up to $6 \mathrm{~h}$ incubation. The nitrogen content of autolyzate at $25^{\circ} \mathrm{C}$ reached the maximum value after $12 \mathrm{~h}$ incubation and thereafter remained constant. The autolyzate at $25^{\circ} \mathrm{C}$ developed a weak foul smell after $24 \mathrm{~h}$ incubation, suggesting the propagation of microorganisms. The extractive nitrogen of autolyzate at $20^{\circ} \mathrm{C}$ increased slowly after $6 \mathrm{~h}$ incubation, reaching the maximum value at $24 \mathrm{~h}$ incubation. The autolyzate at $20^{\circ} \mathrm{C}$ didn't show foul smell after $24 \mathrm{~h}$ incubation, but showed a weak foul smell after $48 \mathrm{~h}$ incubation. In the autolyzates at 10 and $15^{\circ} \mathrm{C}$, such foul smell was not found. Therefore, in the next experiment, autolysis of the head and viscera mixture was performed at $15^{\circ} \mathrm{C}$ for $24 \mathrm{~h}$ to prevent the sample from decaying despite the slightly lower recovery of protein at $15^{\circ} \mathrm{C}$ than that of the autolysis at 20 and $25^{\circ} \mathrm{C}$.

\section{Effect of Shaking Treatment on the Autolysis Efficiency}

The effect of shaking treatment on the recovery during autolysis was investigated. The head and viscera mixture (head:viscera: water $=3: 1: 8$ ) was homogenized and then autolyzed at $15^{\circ} \mathrm{C}$ for $24 \mathrm{~h}$. The increase in extractive nitrogen content are shown in Fig. 2. The result showed that the shaking treatment during autolysis had no significant effect on the extractive nitrogen content. However, the con- 


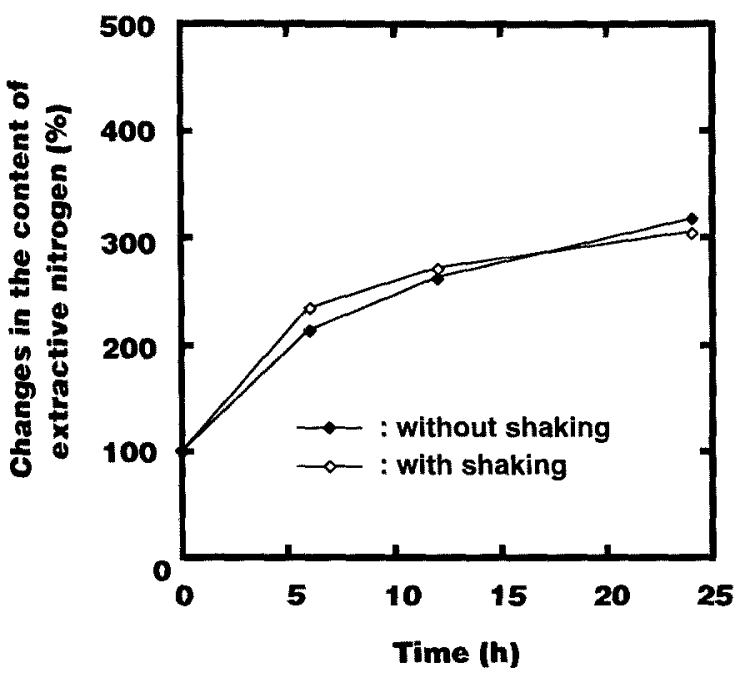

Fig. 2. Effect of shaking treatment during autolysis on the autolysis efficiency of the fish wastes.

Table 2. Free amino acid compositions of autolytic extract prepared from the wastes with and without shaking

\begin{tabular}{|c|c|c|c|}
\hline \multirow{2}{*}{$\begin{array}{l}\text { Amino } \\
\text { acids }\end{array}$} & \multirow{2}{*}{$\begin{array}{l}\text { Before } \\
\text { autolysis }\end{array}$} & \multicolumn{2}{|c|}{$\begin{array}{c}\text { After } \\
\text { autolysis }\end{array}$} \\
\hline & & $\begin{array}{l}\text { Without } \\
\text { shaking }\end{array}$ & $\begin{array}{c}\text { With } \\
\text { shaking }\end{array}$ \\
\hline Tau & 343 & 354 & 342 \\
\hline Asp & 84 & 465 & 393 \\
\hline Thr & 59 & 280 & 241 \\
\hline Ser & 70 & 313 & 276 \\
\hline Glu & 141 & 605 & 518 \\
\hline Gin & 66 & 228 & 196 \\
\hline Gly & 52 & 225 & 180 \\
\hline Ala & 104 & 433 & 395 \\
\hline Val & 73 & 359 & 319 \\
\hline Met & 47 & 200 & 162 \\
\hline Ile & 61 & 337 & 285 \\
\hline Leu & 110 & 556 & 491 \\
\hline Tyr & 61 & 297 & 263 \\
\hline Phe & 61 & 278 & 252 \\
\hline Lys & 124 & 550 & 448 \\
\hline His & 138 & 252 & 199 \\
\hline Arg & 104 & 322 & 333 \\
\hline Pro & 59 & 247 & 213 \\
\hline Total & 1758 & 6300 & 5506 \\
\hline
\end{tabular}

tent of the free amino acids except taurine (Tau) and Arg were lower in the autolyzate with shaking than without shaking (Table 2). In addition, the color of the autolyzate which was shaken was much more brown than the autolyzate without shaking and the bitterness of the former was stronger than the latter. This implies that the bitterness of the extract was enhanced by shaking the sample during autolysis. These results suggest that autolysis should be done without shaking. The reason for the enhanced bitterness by shaking during autolysis remains unclear and needs to be clarified further.

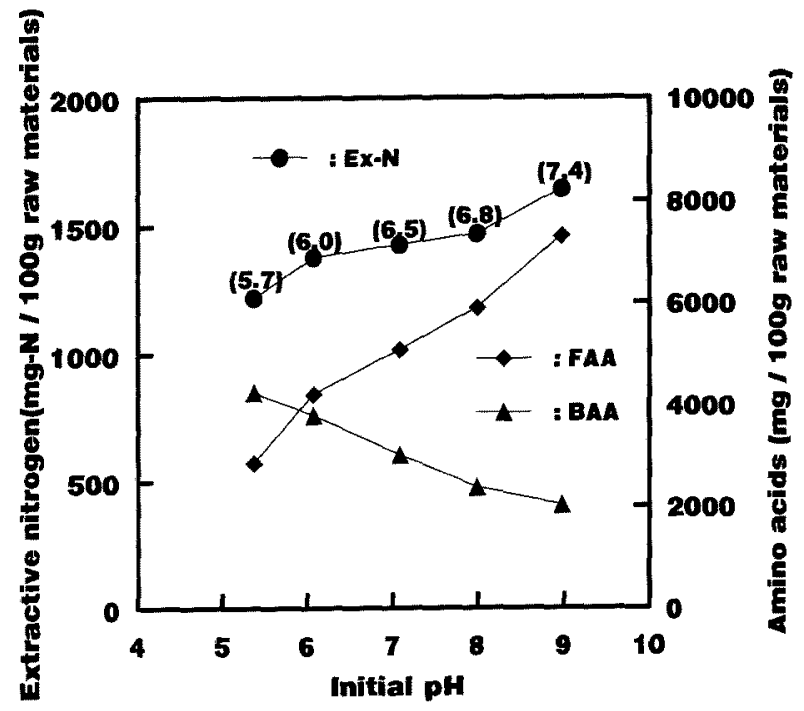

Fig. 3. Effect of pH on the extractive nitrogen, the cotent of free and bound amino acids in the autolyzate of the fish wastes.

Abbreviations in the figure are as follows: Ex-N, extractive nitrogen; FAA, free amino acids; BAA, bound amino acids.

\section{Effect of $p H$ on Autolysis}

Optimum $\mathrm{pH}$ for the autolysis was investigated. Before onset of autolysis, the initial $\mathrm{pH}$ of the head-viscera mixture samples were adjusted to different set values by an addition of $1 \mathrm{~N} \mathrm{HCl}$ or $1 \mathrm{~N} \mathrm{NaOH}$. The original $\mathrm{pH}$ of the head-viscera mixture without $\mathrm{pH}$ adjustment was around 6.8. The mixture was then autolyzed at $15^{\circ} \mathrm{C}$ for $24 \mathrm{~h}$ without shaking. The contents of extractive nitrogen, free and bound amino acids are shown in Fig. 3. The number in the parentheses shows the $\mathrm{pH}$ value of each autolyzate at $15^{\circ} \mathrm{C}$ for $24 \mathrm{~h}$. The extractive nitrogen gradually increased with an increase of initial $\mathrm{pH}$. The content of free amino acids of the autolyzate at $\mathrm{pH} 9$ was much higher

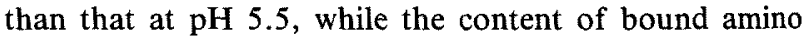
acids of the former was lower than that of the latter. The result showed that the $\mathrm{pH}$ adjustment before autolysis not only affected the increase in the extractive nitrogen of the autolyzate, but it also affected the content of free and bound amino acids of the autolytic extract. This suggests that, in terms of protein recovery autolysis at $\mathrm{pH} 9$ might be suitable for preparation of extract. However, in terms of organoleptic property the autolytic extract prepared at pH 9 had more bitterness as well as umami taste than that of at pH 7. Therefore, this further implies that the $\mathrm{pH}$ adjustment is not necessary for the autolytic extract preparation from the viewpoint of taste and ease of preparation of the extract although the recovery of protein in the autolyzate prepared at neutral $\mathrm{pH}$ was a little lower than that of at alkaline $\mathrm{pH}$.

From the results presented here, we concluded that autolysis at $15^{\circ} \mathrm{C}$ for $24 \mathrm{~h}$ at neutral $\mathrm{pH}$ is suitable for recovery amino acids from the protein in the head and viscera of frigate mackerel. In the last trial, autolytic extract was prepared under above mentioned conditions and the amino acid composition of the extract was investigated.

As shown in Table 3, extractive nitrogen content of the autolytic extract increased from $315 \mathrm{mg}$ to $1584 \mathrm{mg}$ per 
Table 3. Free and bound amino acid compositions of extracts of the wastes before and after autolysis

\begin{tabular}{|c|c|c|c|c|}
\hline \multirow{2}{*}{$\begin{array}{l}\text { Amino } \\
\text { acids }\end{array}$} & \multicolumn{2}{|c|}{ FAA $^{* 1}$} & \multicolumn{2}{|c|}{$\mathrm{BAA}^{* 1}$} \\
\hline & before & after & before & after \\
\hline Tau & 384 & 397 & - & - \\
\hline Asp & 40 & 373 & 35 & 169 \\
\hline Thr & 29 & 215 & 24 & 10 \\
\hline Ser & 34 & 261 & 26 & 77 \\
\hline Glu & 89 & 516 & 112 & 402 \\
\hline Gln & 43 & 154 & - & - \\
\hline Pro & 23 & 173 & 30 & 99 \\
\hline Gly & 28 & 163 & 61 & 238 \\
\hline Ala & 64 & 404 & 25 & 90 \\
\hline Val & 35 & 310 & 21 & 89 \\
\hline Cys & - & 9 & 10 & 43 \\
\hline Met & 22 & 182 & 6 & 12 \\
\hline lle & 28 & 294 & 10 & 49 \\
\hline Leu & 52 & 496 & 17 & 66 \\
\hline Tyt & 31 & 287 & - & - \\
\hline Phe & 30 & 261 & - & - \\
\hline Lys & 54 & 465 & 45 & 142 \\
\hline His & 150 & 577 & 5 & 28 \\
\hline Arg & 44 & 213 & 14 & 31 \\
\hline Total & 1180 & 5450 & 441 & 1636 \\
\hline $\mathrm{EX}-\mathrm{N}^{*}$ & 315 & 1584 & - & - \\
\hline
\end{tabular}

* FAA, free amino acids; BAA, bound amino acids.

${ }^{*}$ EX-N, extractive nitrogen (mgN/ $100 \mathrm{~g}$ sample).

$100 \mathrm{~g}$ head-viscera mixture. From the data in Table 1 , the content of protein nitrogen except alkali-insoluble protein in $100 \mathrm{~g}$ head-viscera mixture was estimated to be $1464 \mathrm{mg}$. This indicated that $87 \%$ of protein nitrogen was recovered as extractive nitrogen by autolysis at $15^{\circ} \mathrm{C}$ for $24 \mathrm{~h}$. In the extract before autolysis, Tau, a non-proteinious amino acid was the most abundant and accounted for $33 \%$ of free amino acid. In the autolyzate, the total content of free amino acid was about 3 times higher than that of bound amino acid. Among the free amino acids, His, Glu, Leu, Lys and Ala were rich (over $400 \mathrm{mg}$ ) in the autolyzate fol- lowed by Tau, Asp, and Val.

This study reveals that the protein in the fish wastes can be efficiently and easily autolyzed even at low temperature. Organoleptically, the autolytic extract possesses umami taste and weak bitterness. Despite weak bitterness, the umami taste emphasizes its potential to be used as a seasoning material. The taste of the autolytic extract could be improved by reducing the bitterness. Further studies to improve the taste of the autolytic extract are now under progress in our laboratory.

Acknowledgments We thank Mr. D. P. Thakur for his critical reading of the manuscript. This study was partly supported by a Grant-in-Aid for scientific research (B) (No. 08456105) from the Ministry of Education, Science, Sports, and Culture of Japan.

\section{References}

1) K. Morioka, S. Sakai, C. Takegami, and A. Obatake: The seasonal changes in lipids of frigate mackerel Auxis rochei. Nippon Suisan Gakkaishi, 65, 732-738 (1999).

2) Y. Miyake: Solubilization of fish scrap by enzyme treatment. Nippon Shokuhin Kogyo Gakkaishi, 29, 117-122 (1982).

3) Y. Miyake: Enzymatic digestion of fish scraps in bench scale production. Nippon Shokuhin Kogyo Gakkaishi, 29, 316-319 (1982).

4) Y. Miyake: Koji mold fermentation treatment of enzymatic digest of fish scraps. Nippon Shokuhin Kogyo Gakkaishi, 29, 366-371 (1982).

5) Y. Miyake: Semi-commercial production of seaasoning from fish scraps. Nippon Shokuhin Kogyo Gakkaishi, 29, 428-434 (1982).

6) V. Mohr: Enzymes technology in the meat and fish industries. Process Biochem., 15, 18-21 (1980).

7) Z. Ooshiro: Some properties of proteinase from the pyloric caeca of mackerel. Nippon Suisan Gakkaishi, 37, 145-148 (1971).

8) R. Yoshinaka, M. Sato, N. Tsuchiya, and S. Ikeda: Production of fish sauce from sardine by utilization of its visceral enzymes. Nippon Suisan Gakkaishi, 49, 463-469 (1983).

9) S. K. Kim, Y. J. Jeon, H. G. Byeun, Y. T. Kim, and C. K. Lee: Enzymatic recovery of cod fram proteins with crude proteinase from tuna pyloric caeca. Fisheris Sci., 63, 421-427 (1997).

10) N. F. Haard: A review of proteolytic enzymes from marine organisms and their application in the food industry. J. Aquat. Food Prod. Tech., 1, 17-35 (1992). 